\section{Multidisciplinary SCIENTIFIC JOURNAL OF MARITIME RESEARCH}

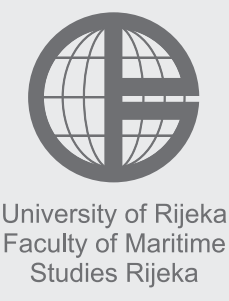

\section{Multidisciplinarni \\ znanstveni časopis \\ POMORSTVO}

\title{
Assessing impact of cruising tourism in Slovenia
}

\author{
Maja Uran Maravić ${ }^{1}$, Daniela Gračan², Željko Zirdum ${ }^{1}$ \\ ${ }^{1}$ Faculty of Tourism Studies University of Primorska, Slovenia, e-mail: maja.uran@fts.upr.si, zeljko.zirdum@gmail.com \\ ${ }^{2}$ University of Rijeka, Faculty of Tourism and Hospitality Management, Croatia, e-mail: danielag@fthm.hr
}

\section{ARTICLE INFO}

\section{Review article}

Received 8 April 2017

Accepted 26 April 2017

Key words:

Cruise tourism

Port of call

Economic impact

Tourism stakeholder

Slovenia

\section{Introduction}

Cruise tourism is the fastest growing sector of nautical tourism, as many authors claim in tourism [4] [5] [10] [14] [19] [6]. This fact makes the cruise tourism a very attractive tourism product for worldwide destinations and many seek to get a piece of the market. The growth of a cruise industry is associated with a number of regulatory and policy developments as the tourism (and other) authorities become aware of its benefits but also its negative impacts [14]. In terms of tourism development and planning, tourism authorities always seek to maximize positive impacts of different sectors of tourism and minimize negative impacts. They are willing to invest into the development of certain sectors of tourism if the positive impacts are high and they have a strong support of local tourism stakeholders.

The nautical tourism in Slovenia began in the late 1960s. In Slovenia, there are three specialised ports for yachts - the three marinas. There are additional public quays in all three municipalities of the Slovenian Istria and at the yacht centre in Izola. Cruise ships docking takes place in the Port of Koper. Cruise tourism has existed in Slovenia since 2005, when the first cruise ship docked at the Port of Koper, marking a consistent rise of arrivals since then [12].

The purpose of this paper is to demonstrate some perceived impact of cruise tourism in Koper and consequently in Slovenia. The main contribution is to show how local hospitality establishment owners as tourism stakeholders perceive the impact of this sector of tourism on the local community.

\section{Cruise tourism}

Nautical tourism is a very broad notion. Nautical tourism includes all types of voyages by sea, and boating on rivers and lakes [12]. Cruise ships were the first large vessels built on purpose for vacation and relaxation rather than commerce and freight. Over the years, this type of voyage has become an integrated experience offering visits to various places for fun and recreation in a relatively short period. Some definitions for cruises are listed below [12]:

- A cruise is a vacation on board a craft.

- Cruises take place on board all kinds of crafts, particularly yachts, sailing boats or motorboats. These days, 
cruises are defined primarily as sailing to tourism-related destinations on board large, luxurious ships that can accommodate over 3,000 passengers.

- Cruises are voyages by sea on board a vessel for the purpose of entertainment, usually at several ports of call.

- Cruises are a luxurious form of a voyage, which include all-inclusive vacations on board a cruise ship for at least 48 hours with a specific itinerary where the passenger ship visits (different) ports or places.

- Cruises are longer seagoing voyages on a fixed route, purposefully and frequently revised.

Cruises are sailing by sea or inland waterways on a predetermined route. The purpose of cruising is entertainment, sports, education, or visiting specific destinations. Cruise tourism is a luxurious form of travelling, involving an all-inclusive holiday on a cruise ship of at least 48 hours, according to specific itinerary, in which the cruise ship calls at several ports or cities [17]. They are usually divided in home port and ports of call. From operational perspectives, efficient cruise ports help to support schedule reliability and allow a continuous passenger transfer to onward flies and/or day excursions. For cruise lines, the diversity of itineraries being offered is the incentive to increase the number of cruises but also to add new ports in their itineraries, particularly on new markets [14].

The facilities and service attributes of cruise ports are crucial to the cruise experience of a growing number of passengers. This experience is also conditioned by the sequence (and therefore the choice) of ports of call, since each port offers different amenities and therefore a different passenger experience. Yet, whereas the requirements and thus the performance attributes of cruise ports differ from what is the case of cargo ports, the literature on cruise ports is scarce and does not cover well the recent developments in this industry [14].

Cruise tourism is reported and discussed by many authors. Authors have given a general description of cruise tourism [17] [14] [6]. They have also discussed different cases of development of the cruise tourism all around the world. [4] [11] [12] [13] [19]. They have analysed impacts of cruise tourism, [5] [2] [1] as well as the characteristic of cruise tourists [1] [16]. A large scope of researches on nautical and cruise tourism has been carried out in Croatia as well [11] [15] [7] [8] [9]. In the following part, some of the listed studies will be discussed.

Pallis et al. have made a strong review on issues concerning the research on cruise tourism. They stated that the future growth potential will require more careful considerations of the market and the physical capacity of some ports and their regions to accommodate cruise itineraries as well. They have suggested that the future research is likely to underline what these potentials could be and the factors that will constrain them [14].

Marti has researched into trends in the cruising industry in the years 1985-2002. His main contribution has been the following one - only ships possessing certain at- tributes can offer world and extended-length cruise options and the daily world cruise price is more expensive as compared to those on an extended-length cruise [13].

Diedrich has analysed, from different angles, the development of cruise tourism on the Caribbean island of Belize. She has concluded that all types of tourism in Belize have the potential to generate negative impacts and are vital. She has suggested to the Belizean government to create a synergy between the cruise tourism and national tourism policies. Namely, the Belizean government failed to enforce self-imposed restrictions on the cruise tourism growth [4].

Weeden et al. have discussed the maturity of certain markets of cruise tourism and its characteristic. They have found the evidence of this maturity in the sector's continued commissioning and bringing into service everlarger ships, which are able to offer an extensive range of facilities and on board activities, such as sports amenities, health and wellness spas, celebration venues, children services and enhancement opportunities. In addition to innovations in the ship design, there has been a considerable investment in the development of the exciting itineraries and the provision of new and emerging ports of call. They have stated that, as a consequence of these and other expansion activities, the majority of the cruise operators are now able to offer more specialized or customized services [19]. Their findings have been very important for the Adriatic area, since this area is now slowly maturing and it does not need to repeat all he mistakes made on the Caribbean.

Dwyer and Forsyth have discussed the economic impacts of cruise tourism. They have tried to develop a framework for assessing the economic impacts of cruise tourism for a nation and its sub regions. They have argued that the framework is of a value in considering policy towards cruise tourism. The knowledge of impacts can be valuable in planning infrastructure. They have also stated that it is possible to examine the advantages and disadvantages, from a regional and national viewpoint, of measures designed to encourage cruise tourism, if impacts and net benefits are calculated [5].

Brida et al. have also focused on economic impacts. They have done researches on cruisers' experience and the economic impact of cruise tourism on the specific case of a home port destination. They have analysed in detail spending characteristics of a cruise tourist in the South America's home port of Cartagena de Indias. Their detailed analysis of cruise tourists has set up a strong foundation for a decision making regarding the development of cruise tourism [1].

Butt has talked about waste produced on board cruise ships and its impact. She has stated that cruise ships represent less than $1 \%$ of the global merchant fleet, yet it has been estimated that they are responsible for $25 \%$ of all waste generated by merchant vessels. She has concluded that all cruise vessels should vigorously pursue a waste reduction strategy and for ports to provide adequate re- 
cycling, reduction and re-use facilities for the cruise ship generated waste, optimising the use of local facilities whenever possible [2].

Klein has advocated the responsible development of cruise tourism. His goal has been to illustrate how a responsible tourism lens measures the impact of cruise tourism and, with its focus on the perceptions of host communities, more effectively addresses grassroots concerns. He has used the case examples to identify and describe challenges faced by governments, communities, and the cruise industry. He has firmly believed that the analysis of these issues and challenges gives direction for how cruise tourism can grow in such a way that both are sustainable and responsible [10].

Pranić et al. has focused on the comparison between small and large cruise ship. They have argued that, while international micro-cruises present a new and exciting tourism segment and a potentially powerful promotional tool for some countries and coastal destinations, the growing body of cruise research has focused almost all attention on large international cruises and on-board experiences. Their results have revealed significant differences in the voyagers' demographics/tripographics and satisfaction with different coastal destination attributes between the two cruise segments [16].

\section{Cruise tourism impacts}

There are different positive and negative impacts of cruise tourism. Most authors state environmental, sociocultural and economic impacts [4]. The economic impact of cruise tourism on host economy is generally positive but also carries some negative aspects. It is important to establish how the significant cruise tourism spending is related to an economy because this allows tourism authorities to determine decency and to develop tourism strategies [3].

In the attempt to comprehend the potential economic significance of cruise tourism, Dwyer and Forsyth have arisen several questions [5, p. 394]:

- What are the economic impacts of cruise tourism?

- To what extent does foreign ownership of cruise ships limit the economic impacts of this form of tourism?

- Will these impacts be concentrated in stopover port areas or distributed nationally?

- What are the potential net benefits (as compared to economic impacts) of cruise tourism regionally and nationally?

According to Dwyer and Forsyth, the existing literature typically contains either superficial answers or even none ones to such questions, despite their general importance to any country wishing to understand the economic significance of this sector of tourism [5].

There are several potential impacts of cruise tourism for a port. It is important to distinguish between the behaviour of the passengers who are either at the beginning of their voyage or are calling in the destination within the cruise voyage. Cruise passengers making a short stop are visitors of a port of call where cruise ships are berthed. During their short visit (on an average of 6 hours), passengers have the opportunity to visit the main attractions of the destination, to do some shopping, take land tours and enjoy in other activities [1].

Different stakeholders can see impacts of cruise tourism differently. The stakeholder's theory, therefore, requires tourism authorities to consider the full range of stakeholders in their unique operational setting and to ensure the involvement of these actors to build a strong network of stakeholders for a successful development of any tourism destination [18].

\section{Cruise tourism in Slovenia}

Nautical tourism began to develop in Slovenia in the late 1960s. Slovenia has three marinas. Marina Portorož was the first marina opened in Slovenia in 1970, followed by Marina Koper in 1990 and Marina Izola in 1994. Beside marinas, there are a few moorings and a passenger terminal in the city of Koper. Despite its small coastal strip (46 $\mathrm{km}$ ), all forms of nautical tourism are represented.

As the authors have reported a rapid growth [17] [4] [5], cruise tourism is the largest emerging economy in Slovenia as well. Although Koper, as a port of call, has not yet developed to the scale of Croatian ports, some impacts can already be seen. The impact of cruises has been well described in a study of the economic effects of the Koper passenger terminal: "When one must assess what impact the cruise industry has on an area, and one must also assess tourism-based consumption, one must be aware that consumption is the result of tourist behaviour, and that there are different categories of tourists. This is especially true at the Port of Koper, which offers a wide range of tours, not only in regard to the location, but also the mix of tour possibilities. These can be for excursions around Koper as well as for trips to a variety of Slovenian destinations in different arrangements. Slovenia has been able to capitalise on its particular natural beauty and is attractive to both European and international tourists. The decision to promote itself as a green country, was seen not only as a logical, but also as a winning proposition: over two-thirds of the Slovenian territory is protected, comprising over eight thousand caves; in a compact area offering coastline and mountains, as well as numerous thermal springs with highly-developed wellness tourism. Since the introduction of cruise tourism to Koper, it has been an economic centre for visitors to Slovenian Istria offering many different options: city centre tours, Regional Museum, the Praetorian Palace and Loggia, and streets around Tito Square capturing within them the memory of the "Venetian period" [12].

In the following part, we shall present data on the number of incoming cruise ships in detail and the number of passengers carried by them for the period from 2005 to 2015. 
Table 1 Number of Incoming Cruise Ships and Passenger Numbers from 2005 to 2015

\begin{tabular}{|c|c|c|}
\hline Year & No. of cruise ships & No. of passengers \\
\hline 2005 & 18 & 1,100 \\
\hline 2006 & 18 & 1,800 \\
\hline 2007 & 54 & 22,580 \\
\hline 2008 & 44 & 15,246 \\
\hline 2009 & 53 & 31,021 \\
\hline 2010 & 55 & 108,820 \\
\hline 2011 & 78 & 64,455 \\
\hline 2012 & 47 & 65,439 \\
\hline 2013 & 54 & 58,974 \\
\hline 2014 & 49 & 57,893 \\
\hline 2015 & 65 & 73,000 \\
\hline
\end{tabular}

Source: Maravić Uran et al. (2016)

Table 1 shows that 18 cruise ships arrived at the Port of Koper in 2005 and 65 in 2015. We have found that, since the 2005 opening of the passenger terminal in the Port of Koper, each year has had a greater number of cruise ship arrivals. The reason for this is most likely the targeted and deliberate investment by the Luka Koper in their passenger terminal. Another reason could be the arrival of new shipping companies at Koper. What has to be also observed in Table 1 are the passenger numbers at the Port of Koper, which reported 1,100 passengers in 2005 and 73,000 in 2015 [12]. If we compare these numbers to Croatian ports, we can see, that Koper has approximately one tenth of cruise ships of Dubrovnik [15]. There is still a great potential to grow, especially if the cruise tourist can be evenly distributed to take excursions across all major attractions in Slovenia.

\section{Research methodology}

As evident from Table 1, Koper has become a popular port for cruise ships, cruising on the Adriatic Sea. Given the rapid development of this tourism sector in Koper and Slovenia, we have decided to ask the owners of hospitality establishments (bars and restaurants), how they perceive the impacts of cruise tourism. These tourism stakeholders are collected deliberately, as hoteliers do not generally have direct benefits from cruise tourists. This was done because there is a lot of evidence from Croatian ports where the local hospitality establishments are dissatisfied with the visit and consumption of cruise tourists [15]. The analysis has focused on nine owners of hospitality establishments in the city of Koper, where the port for cruise ship is located.

The purpose of this study is to examine the opinion of the owners of hospitality establishments, regarding cruise tourism in general and its impacts. The semi-structured interview was used for the survey, because there are not many providers in the destination.
The semi-structured interviews have been carried out by asking the following questions:

1. What do you think about the arrival of large cruise ship in the city of Koper?

2. What do you think about the tourist coming by cruise ships?

3. Do you gain any income from cruise tourists?

4. What do you think about tourism/hospitality offer in Koper?

5. What do you think are the major shortcomings of the existing tourism/hospitality offer?

6. Would you like to have more cruise tourist? What are your expectations?

7. What would you do to gain more cruise tourists?

8. What do you think about the fact that cruise tourists go on excursions all around Slovenia and do not stay in the city of Koper?

9. Would it help in getting more revenue from cruise ships, if Koper were the home port?

10. How do you assess your own offer?

\section{Results}

The answers to the questions put to owners of hospitality establishments are presented below. The owners have been asked what they think of the arrival of large cruise ships at Koper. On this issue, most of them have given a positive answer; most of them believe this is a niche opportunity and a good thing, which provides added value for the city.

The next question relates to how they feel about cruise tourists. On this question, the owners do not have anything negative to say. In fact, they are very positive. They report that cruise tourists are very good people, who are pleasant and positive. Some also have the opinion that such tourists bring liveliness and action to the city. Most of the questioners have said that it also depends on the type of cruise ship since this affects the purchases made by these tourists.

Asked whether they have made any income, the majority have replied in the affirmative. Six owners have said that they have some income from these tourists. As regards their catering offers, the owners have different opinions. As can be seen from the answers, two out of the nine questioners have suggested that there are too many bars, and restaurant offers are limited. Others have argued that the offers are good. Only one questioner, whose establishment is not located at the seaside, is of the opinion that offers next to the sea vary somehow.

Regarding the shortcomings in hospitality offers, each owner has expressed its own opinion, giving views completely different to owners of other establishments. Each owner has recognised its own shortcomings, but they have not able to disregard other significant shortcomings. Those owners, who have had the influence, would take the opportunity or possibility to remedy or partly make changes. All 
have agreed that there are too many pubs of a lower quality, criticising their speed of service, lack of friendliness and lack of eagerness to work. They have warned of price dumping and the lack of specialised food offers at seaside establishments.

Different opinions have been given to the question of what expectations do hospitality owners have in relation to cruise tourists. Owners in the city centre have said that it is subject to a "more guests, more revenue" rule. Three have not answered the question and other two have had no expectations of cruise tourists. It is highly important for owners of seaside establishments, that tourists, wandering along the promenade, can stop (and stop for refreshments) and that these owners have to be happy for each visit. One of them has stated that they like to serve every guest, as each one is important due to the higher costs imposed by a "hungry state".

The question on what changes are needed to attract more cruise tourists - many different answers have been given. Owners have reported that their offers are good, and that they are satisfied with the current situation. Another one would be satisfied with making changes to marketing approaches. One of the owners has indicated that they would explore wishes by conducting their own survey of tourists and diversifying their offer. Another has suggested that there should be more shuttle trains and events aimed at attracting tourists so they would spend more time in the city. One has stated that they are not in the right location, so whatever might be done, would not be effective, while others have said that guests cannot find their catering establishments because they are far away from the centre of the city. Quality, ambience or orderliness and friendliness have also been issues mentioned. They have also revealed that diverse offers, quick service, variety and freshness of food are important too. One of the questioners has specifically pointed out that "a satisfied guest will return." Generally speaking, there have been no ideas of what kind of approaches to take in order to attract more guests. Another one has said that there are many ideas, but no certainty of a pay-off. The remaining questioners would like to attract newcomers through leaflets, brochures, various promotions and (improvements to the) quality and ambience.

Another related issue is that most cruise tourists go on trips around Slovenia and do not remain in Koper. Surprisingly, hospitality owners do not see that as a problem. They have explained that this is a very positive and right offer, since guests should not be limited to the city of Koper. They have claimed that this is a good thing in a long term view, because cruises will wish to come back because of the wide range of offers intended to their passengers. They have said that such an option is also worthy of, because there is a possibility of going on a sightseeing tour of the whole of Slovenia. Only one has stated that such an offer is very good for tourists, but not for the owners, as guests spend their money then somewhere else.

Owners have been also asked what they think of Koper becoming a cruise ship home port. The given answers have made it clear that most of them agree with this idea. Seven owners have believed that it will make a real contribution to their income. One questioner has not answered this question, while one has disagreed with this. Most of them have mentioned that by the arrival of every single guest or tourist they will profit and that this would be the right move.

Finally, we have asked, how they rate their own offers. Four giving themselves a very good rating, two have suggested that they could always do better, one has pointed out that guests appraise their work, and one has said that space constraints are the greatest issue.

\section{Discussion and conclusion}

Hospitality establishment owners in the city of Koper approve the new opportunities and marketing of niche cruising, which are developing very rapidly, and today represent mass tourism as a product accessible to everyone and a mass influx of tourists taking it up. Koper has been a fixture on the Mediterranean cruise routes for some years and is becoming an important destination for large and well-known cruise ship operators with many additional tourist offers both from the ship operators and the passenger cruise lines as well. Koper will likely have more such passengers, so owners can stick to the strong promise of an extra income, which will bring benefits. Owners need only to somehow attract tourists and be able to deliver the right offers and get, for however long they stay, repeat visits. Given that this type of tourism is developing, we have been anxious to know what the opinions of hospitality establishment owners in the city of Koper are and whether they are satisfied with.

At the end, we have compiled a survey by using a semistructured interview. From the answers obtained, we can see that the owners have expressed positive opinions and made good suggestions regarding cruise tourists. Nobody gets excited about being overrun by cruise tourists, but every euro spent by cruise passengers brings a benefit.

Finally, let us emphasize that cruise tourism in Koper and in Slovenia as well is at an early stage of its development. Therefore, most of the problems noted in more developed ports by other authors, have not existed in Koper and in Slovenia as yet. Hospitality offering for cruise tourists is perceived positively, because it is obvious that this type of tourism, that could also bring trouble, is not yet overwhelming. Compared to Dubrovnik, which is the largest cruise port in Croatia [14], there is (really) no comparison, because Dubrovnik enjoys up to 10 times more tourists, who are mostly sightseeing around the old city that struggles to deal with such numbers. Certainly, cruise tourism is not only important for Koper, but for the entire country, as it has a diversity of interesting tourist products for ship operators, who are always seeking exciting new destinations and itineraries for their passengers [14].

We would also like to mention the deficiencies and recommendations for further research. The main drawback of this research is naturally the number of interviewees. 
However, it is a fact that there are few catering establishments in the old city centre of Koper and these are already located at the most important locations in the city, and visited by cruise tourists. Many owners did not want to participate in this survey. Another deficiency relates to how effectively tourism stakeholders have answered the questions in order to be able to determine what impact cruise tourism has on the local destination. Some answers have opened up questions for a further study. There is a concern that cruise tourism is not a sustainable form of tourism, purely because of the number of tourists involved [4]. And in conclusion, we recommend that local communities draw up a detailed methodology for monitoring the impacts of cruise tourism to their local destination. We have started from the point that the sustainable development, sought by Slovenia, must balance the positive economic and negative environmental impacts of the tourism sector on the local environment [11].

\section{References}

[1] Brida, J. G., Pulina, M., Riaño, E. and Sandra, Z.-A.: “Cruise passengers' experience embarking in a Caribbean home port. The case study of Cartagena de Indias," Ocean \& Coastal Management 55, pp. 135-145, 2012.

[2] Butt, N.: "The impact of cruise ship generated waste on home ports and ports of call: A study of Southampton," Marine Policy 31, pp. 591-598, 2007.

[3] Cooper, C. Fletcher, J., Gilbert, D. and Wanhill, S.: Tourism: Principle and Practice, Harlow: Pearson Education Limited, 2005.

[4] Diedrich, A.: "Cruise ship tourism in Belize: The implications of developing cruise ship tourism," Ocean \& Coastal Management 53, pp. 234-244, 2010.

[5] Dwyer, L. and Forsyth, P.: "Economic significance of cruise tourism," Annals of tourism research 25 (2), pp. 393-415, 1998.

[6] Gibson, P.: "Cruising in the 21st century: Who works while others play?," International Journal of Hospitality Management 27 , pp. 42-52, 2008.
[7] Gračan, D.: "The Role of Strategic Management in The Cruising Tourism Market," Pomorski zbornik 51, pp. 103-116, 2016.

[8] Gračan, D. and Zadel, Z.: "Kvantitativna i kvalitativna analiza kruzing turizma Republike Hrvatske," Pomorski zbornik 4748 , pp. 51-59, 2013.

[9] Jugović, A., Kovačić, M. and Hadžić, A.: "Sustainable development model for nautical tourism ports," Tourism and Hospitality Management 17 (2), pp. 175-186, 2011.

[10] Klein, R. A.: "Responsible Cruise Tourism: Issues of Cruise Tourism," Journal of Hospitality and Tourism Management, 18, p. 107-116, 2011.

[11] Kovačić, M., Gračan D., Jugović, A.: "The scenario method of nautical tourism development - a case study of Croatia," Scientific Journal of Maritime Research 29, pp. 125-132, 2015.

[12] Maravić Uran, M., Martinič, N. and Barkiđija Sotošek, M.: "An Analysis of Nautical and Cruise Tourism in Slovenia (20052015) and its positioning amog Meditteranean other countries," Pomorski zbornik 52, pp. 113-131, 2016.

[13] Marti, B.: "Trends in world and extended-length cruising (1985-2002)," Marine Policy 28, p. 199-211, 2004.

[14] Pallis, A. A., Rodrigue, J.-P. and Notteboom, T. E.: “Cruises and cruise ports: Structures and strategies," Research in Transportation Business \& Management 13, p. 1-5, 2014.

[15] Perić, T. and Oršulić, M.: "Cruising tourism in The Republic of Croatia contributing to sustainable development," Naše more 58(5-6), pp. 219-228, 2011.

[16] Pranić, L., Marušić, Z. and Sever, I.: “Cruise passengers' experiences in coastal destinations e Floating "B\&Bs" vs. floating "resorts": A case of Croatia," Ocean \& Coastal Management 84, pp. 1-12, 2013.

[17] R. C. f. C. Tourism, "Cruise Tourism from a broad perspective to a focus on Zeeland," Research Centre for Coastal Tourism, Breda, 2012.

[18] Todd, L., Leask, A. and Ensor, J.: "Understanding primary stakeholders' multiple roles in hallmark event," Tourism Management 59, pp. 494-509, 2017.

[19] Weeden, C., Jo-Anne, L. and Thyne, M.: "Cruise Tourism: Emerging Issues and Implications for a Maturing Industry," Journal of Hospitality and Tourism Management 18, pp. 2629, 2011. 